\title{
Wildlife after the Anthropocene
}

I would like to open by thanking Irus and my three commentators and the other participants in the Wildlife sessions at the AAG in Chicago in 2015, from which this section emerges. These are sympathetic and generous commentaries that draw attention to some of the key themes, contributions and deficiencies in our accounts.

Wildlife in the Anthropocene emerges from over fifteen years of critical, ethnographic work on conservation in various parts of the world. During this period conservation itself has undergone some radical changes. These include the failure of 'biodiversity' as a global governance framework, the continued rise of market environmentalism, a growing openness to 'novel ecosystems', and, most recently, an engagement with the idea of the Anthropocene. As Irus also notes in her book, conservation is moving (quite quickly in some places) beyond the stable and purified notion of Nature that was much criticised by earlier work in geography and cognate disciplines. This book documents these shifts and offers new ontologies, epistemologies and political techniques to guide these changes.

The Anthropocene emerged quite late in the drafting of my manuscript, coincident with its dramatic recent rise to prominence in academic and popular circles. I have found the scientific and political debates around this epochal moment reinvigorating for already established debates in geography about the natures of Nature. But the book is not a celebration of the Anthropocene (as concept or epoch). The name is unfortunate: elevating man while failing to differentiate amongst responsible men. Nonetheless, the political event of the Anthropocene has been extremely generative. Witness for example the ongoing Anthropocene Project at the Haus der Kulturen der Welt in Berlin ${ }^{1}$ or the founding of new interdisciplinary journals ${ }^{2}$.

My book title refers to Conservation after Nature. As we all now know, Nature in any pure and stable form - has never existed. The political event of the Anthropocene popularises diagnoses of the 'End of Nature' that are wellestablished in geography and elsewhere. I had intended to title the book Wildlife after the Anthropocene to acknowledge both the generative potential of the current scientific debate and the possibility of imagining better planetary relations whose subsequent stratigraphy might mark a further epoch - which I speculatively term the Cosmoscene (after Haraway and Stengers). My publishers were not keen on the idea! Nonetheless, my aspiration is to harness the popular and political energies of the Anthropocene moment. I want to narrate and claim the term in the face reinvigorated forms of 'ecomodernism' that promise a

\footnotetext{
1 This project is a large, publically funded initiative bringing together artists, scientists and a host of other scholars to reflect on the concept and implications of the Anthropocene [see www.hkw.de]. The project began in 2013 and has forged close links with The Anthropocene Working Group. This is the interdisciplinary body of scientists working under the umbrella of the International Commission on Stratigraphy and tasked with developing a proposal for the formal ratification of the Anthropocene as an official unit in the Geological Time Scale.

2 See for example The Anthropocene Review and Anthropocene
} 
'\#goodanthropocene' through a largely apolitical and techno-optimist model of business as usual ${ }^{3}$.

My book notes the coincidence between an interest in the Anthropocene and a shift in powerful strands of conservation theory and practice from an emphasis on species composition to the dynamics of ecological processes. My narrative is sympathetic to this shift, especially when it finds expression in enthusiasms for novel ecosystems - like urban ecologies and post-industrial landscapes - and when it offers a dynamic, speculative and democratic model for managing changing ecologies. My sympathies emerge most clearly in my comparison of two different conservation case studies - preserving the composition of traditional, low-intensity agricultural systems in the Scottish Hebrides versus wild experiments with 'de-domesticated' large herbivores grazing a polder landscape in the Netherlands. However, my enthusiasms for the process-orientated conservation expressed in rewilding are a little more nuanced than Becky Mansfield suggests in her comments. I do believe that species and individual animals matter - ecologically, ethologically, economically and culturally. For example, significant and important parts of the book make a case for elephants as wildlife.

One of the central aims of the book - which I develop in the conclusions - is to document the 'ontological politics' at the heart of conservation practice and to find means of conceiving and deliberating tensions between compositionalist and a functionalist approaches. Conservationists acknowledge multiple forms of 'significant difference' and face hard and uncertain choices in deciding what to let 'flourish' - to use Haraway's (2008) terms. Cutting up wildlife as genes, individuals, breeds, cultures, species or ecologies, for example, results in management interventions that enact different natures with real, material and biopolitical consequences for nonhuman life. In addressing these challenges, I suggest that the current revaluation of processes (coupled with new ethical and epistemic practices attuned to surprises) is necessary for a future-orientated conservation - but there are important ecological, ethical, economic and political reasons for valuing species (however charismatic they might be).

Nigel Clark's comments about the generative potential of the 'earthly ground' that underpins biological life are useful for thinking through new ontologies for conservation in the Anthropocene. There are real, nonhuman forms of geo and biopower at play in this story, which both subtend and circumvent human conservation efforts. Biodiversity loss is anthropogenic, but humans are assisted in ecological destruction by a host of invasive species and climatic and hydrological processes. Such powers are often absent from work concerned with the 'construction', 'production' or 'governance' of nature in the political ecology of nature conservation. This book offers a vital materialist account of conservation. It demonstrates how successful conservation has to learn to be affected by such powers and to work with them to secure desirable political ecologies.

${ }^{3}$ See for example An Ecomodernist Manifesto www.ecomodernism.org 
Nigel is right that some conservationists understand these geo and biopowers as Nature. This is a version of his 'Inhuman Nature' (Clark 2011) that enfolds, supports and threatens human and nonhuman life. It has a human signature but it is by no means domesticated. In the face of the planetary shifts predicted to be associated with the Anthropocene, it may seem irresponsible to advocate anthropogenic disturbance and instability; but change is the evolutionary crucible from which biological diversity has emerged and without it valued species and landscapes will not survive. The challenge - as Daniel Botkin (1990) observed several years ago - is to find ways of sensing, conducting or avoiding the 'discordant harmonies' that characterise any ecosystem (novel or otherwise).

In engaging with the ontologies of conservation this book also offers modest means for ontologising the bodies, technologies and knowledge practices of conservationists. I develop my concept of nonhuman charisma to offer a relational ontology for understanding how and why some species, habitats and conservation practices figure so prominently in the scope of contemporary conservation. In his comments, Alex Loftus is concerned about possible essentialisms within this approach - the establishment of a fixed human Anthropos as the agent of conservation science. This is not my intention. I seek to establish consistencies and commonalities in the human affections displayed for particular organisms and to relate these to common biophysical properties amongst sensing human bodies. These properties (like ocular-centrism, terrestriality, diurnal routines, body shape and size) I term ecological charisma. They form the foundations for how we sense the world, but they do not determine value. The values attached to encounters with places and species are historically and geographically variable. These secondary properties I term aesthetic and corporeal charisma. For example, I think it is fair to assume that elephants are sensed and known wherever humans encounter them. But whether they are loved, feared, venerated or hunted varies greatly.

Questions of value are central to the latter chapters of the book in which I examine the affective economies of wildlife on film and in the growing markets for ecotourism - in 'the wild' and in captive settings. I have (and continue) to struggle with theorising the nature of value performed by nonhumans in these encounters. Haraway's (2008) work on encounter value provides a useful starting point - but her reflections are brief and fairly specific to the human-dog relations that are the concern of her book. I believe there is much more that could be done to theorise both the emotional and the ecological labour performed by charismatic animals in these encounters and the alienating and exploitative political ecologies configured by powerful forms of market environmentalism.

Alex is right to draw attention to my ambivalence (and confusion) about commodification in my account of these economies. In many cases the relationships that deliver conservation volunteering and wildlife film mask human and nonhuman injustices. Growing markets have made these products generic spectacles. But there are also compelling examples of paying conservation that deliver local livelihoods, transformative encounters for mobile tourists and viewers, and preferential outcomes for wildlife. The differentiation 
associated with the latter forms of consumption probably disqualifies these encounters as generic commodities and thus Alex's criticism holds. To clarify, I see scope for market mechanisms in wildlife conservation when conscious efforts are made to prick the beguiling bubble that bounds many encounters both proximal and virtual.

Specifying the ethics and politics performed by commodification also helps clarify my take on captivity. Irus is right in her comments to caution against a popular tendency in critical animal studies and some approaches to conservation toward a 'debunking of anything the smells of captivity' on the grounds that it contravenes some essential, pure nonhuman nature. This is not what I was intending in my analysis of the 'captivity paradox': the fact some of the more captivating animals (to humans) are those that seem to fare least well in the captivity practices necessary for commodifying their encounters with humans. In critically engaging with such institutional spaces of captivity I am concerned less with their 'ex situ' or 'intersitu' character and more with the lifeworlds they shape for their nonhuman inhabitants.

I agree that for snails it may matter little if they live in a glass box in London Zoo, on the leaves of my allotment lettuce in Oxford, or in the depths of 'wilds' of the Lake District. As I explain in my book, this is not true for elephants, who are deeply affected by some (though by no means all) of the practices necessary for keeping them visible, even rideable, to paying ecotourists - in zoos and in National Parks. I understand captivity as more of a political and ethical relationship, than a spatial or ontological condition. What is currently understood as ex-situ conservation will no doubt be important in the future. Exsitu encounters with fee-paying publics may even have a role to play. But there are a (fairly small) number of species for whom this type of captivity has important, negative welfare implications.

Ultimately, the Anthropocene epoch is shaping up to be disastrous for many forms of life. But the political event of the Anthropocene offers generative opportunities for thinking and practicing wildlife conservation differently. I believe Irus' and my books offer two interventions into a vibrant and constructive debate on the future of conservation.

\section{References}

Botkin D. 1990 Discordant harmonies: a new ecology for the twenty-first century. New York, Oxford University Press.

Clark N. 2011 Inhuman nature: sociable living on a dynamic planet. Thousand Oaks, CA, SAGE.

Haraway D. 2008 When species meet. Minneapolis, University of Minnesota Press. 